\title{
An Experimental Study of Dietary Therapy on Osteoporotic Mandibular Alveolus in Young Rats
}

\author{
-On Bone Matrix Formation- \\ Yasushi Tsuruta, Takahiro Nishioka, Bin Xia, \\ Kenshi Maki and Masato Uchikanbori \\ Department of Pediatric Dentistry (Director: Prof. Mitsutaka Kimura) \\ Kyushu Dental College, Kitakyushu, Japan
}

Accept on August 25, 2000.

\begin{abstract}
In the present study, we fed thirty young Wistar rats that were in the secondary sexual characteristic period on calcium deficient diet so the osteoporotic mandible, which was thought as a reason for the declining of masticatory force and masticatory ability, was resulted in. After that we researched the effect of dietary therapy on the matrix formation of these osteoporotic mandible. The high calcium diet was made from sea shell, called UNICAL $^{\circledR}$. The results were shown as follows.

1. Microphotometric findings

Significant differences were observed between the control group, calcium deficient . standard diet group, calcium deficient $\cdot \mathrm{UNICAL}^{\circledR}$ group and low calcium $\cdot \mathrm{UNICAL}^{\circledR}$ group (p $<0.01)$. And significant differences were also observed between control group and low calcium $\cdot$ standard diet group $(p<0.05)$.

2. X-ray microanalysis of $\mathrm{Ca}$ and $\mathrm{P}$

By surface microanalysis, it has been found that density of calcium was higher than phosphorus in any group. Significant differences were found in quantitative analysis which was done by calculating the calcium and phosphorus relative proportion against control group, showed as $\mathrm{Ca} /[\mathrm{Ca}] \mathrm{c}$ and $\mathrm{P} /[\mathrm{P}] \mathrm{c}$. The results of $\mathrm{Ca} /[\mathrm{Ca}] \mathrm{c}$ were calcium deficient . standard diet group $<$ calcium deficient $\cdot \mathrm{UNICAL}^{\circledR}$ group $<$ low calcium $\cdot \mathrm{UNICAL}{ }^{\circledR}$ group $<$ low calcium - standard diet group $<$ control group, while $\mathrm{P} /[\mathrm{P}] \mathrm{c}$ showed as control $<$ calcium deficient $\cdot$ standard diet group $<$ calcium deficient $\cdot$ UNICAL ${ }^{\circledR}$ group $<$ low calcium $\cdot$ standard diet group $<$ low calcium $\cdot$ UNICAL ${ }^{\circledR}$ group.

3. Histopathological findings

As contrasted with control group, the enlargement of bone marrow space, the number and thickness of trabeculae decreasing were obvious in calcium deficient-standard diet group. Bone osteopenia were obviously seen such as decrease of the number of lamellae and lacunae. Compared with calcium deficient standard diet group, the calcium deficient $\cdot \mathrm{UNICAL}^{\circledR}$ group showed that bone marrow space decreased and bone remolding was active, but the number of
\end{abstract}


lacunae decreased obviously yet and bone still fell into osteopenia when compared with control group. Thicker new bone was seen in low calcium-standard diet group than in calcium deficient $\cdot \mathrm{UNICAL}^{\circledR}$ group, the number of Haversian system and lacunae increased too. In low calcium. UNICAL ${ }^{\circledR}$ group the formation of bone matrix was the same as what was seen in control group.

Key words: Osteoporosis / Mandibular Alveolus/Dietary Therapy / Bone Matrix / Young Rat

\section{Introduction}

Calcium, the total weight of which in human body is about $2 \%$ of body weight, is a very important mineral and $99 \%$ of it is stored in bone and tooth in the form of hydroxyapatite crystals, which is the key factor for bone to keep its strength ${ }^{1)}$. The other body calcium ion is in cells or blood, which play an essential role in the conduction of nervous stimulant, contract of muscle and metabolism of energy. In order to keep these important functions to be normal, the concentrations of calcium in blood and cells are regulated strictly.

Bone serves as a replenishing base for calcium just as a big store. If the balance of calcium between the absorption in intestine and excretion through urine is kept, the formation and resorption of bone will be balanced, and the metabolism of bone calcium is balanced too. When the absorption of calcium in intestine decreases, in order to keep the normal concentration of calcium in serum, the bone resorption is dominative resulting in the calcium or bone decrease, if the resorption keep a long time, bone will fall into osteopenia. It has been considered that insufficient intake of calcium is a risk factor of osteoporosis.

The most active period of bone growth and development is in childhood, and this growth and development per year reach the most at 17-20 years old ${ }^{2}$. The peak bone mass is reached at the end of this period, after that the absorption of calcium in intestine decrease, and the bone mass decrease with aging, so one of preventive measures of the old osteoporosis should be aimed at maximizing peak bone mass at skeletal maturity.

In the present study, we fed the young rats, which was in the secondary sexual characteristic period, on calcium deficient diet, when the osteopenia of mandible was resulted in, we researched the effect of dietary therapy on the matrix formation of mandible. The high calcium diet was made from sea shell, called $\mathrm{UNICAL}^{\circledR}$.

\section{Materials and Methods}

Thirty 8-week-old male Wistar rats corresponding to the young in human were used. Control group was fed a standard chow (Oriental Yeast, Tokyo, Japan) and tap water for 4 weeks. Calcium deficient standard diet group was fed a calcium deficient rat chow (Oriental Yeast) and distilled water for the first 3 weeks, and then a standard chow and tap water for one week. Calcium deficient UNICAL $^{\circledR}$ diet group was fed a calcium deficient rat chow (Oriental Yeast) and distilled water for the first 3 weeks, and then UNICAL ${ }^{\circledR}$ chow and tap 
water for one week. Low calcium standard diet group was fed a low calcium (30\%) chow (Oriental Yeast, Japan) and tap water for the first 3 weeks, and a standard chow and tap water for one week. Low calcium UNICAL ${ }^{\circledR}$ diet group was fed a low calcium (30\%) chow (Oriental Yeast, Japan) and tap water for the first 3 weeks, and a UNICAL ${ }^{\circledR}$ diet and tap water for one week.

After four weeks, the rats were sacrificed with intraperitoneal injection of pentobarbital sodium (Nembutal, Nippon Pharmacy). The mandible was harvested and fixed in $10 \%$ neutral formalin. Soft radiographs were taken with CSM (ESM-2, Softex, Japan) and Fuji Softex film (FG, Fuji Film), aluminum stepwedge attached, at $35 \mathrm{kVp}, 5 \mathrm{~mA}, 60$ seconds of exposure time, and $70 \mathrm{~cm}$ of focus-to-film distance. Microphotometry was carried out with microphotometer (PDS-15, Konica, Japan), with a beam slit of 10 by $500 \mu \mathrm{m}$, scanning from lower border to alveolar crest to obtain a scanning pattern.

The surface microanalysis of calcium, phosphorus in mandible was investigated by energydispersive $\mathrm{X}$-ray microanalysis (SED-800, Seiko, GE\&G). And then quantitative analysis was done.

The samples were decalcified with $5 \%$ nitric acid and embedded into paraffin 7-micron successive section were cut and stained with hematoxylin and eosin then observed by microscope.

Statistical significance was tested by $\mathrm{F}$ test.

\section{Results}

1. Microphotometric findings

Significant differences were observed between the control group, calcium deficient . standard diet group, calcium deficient $\cdot \mathrm{UNICAL}^{\circledR}$ group and low calcium $\cdot \mathrm{UNICAL}^{\circledR}$ group (p $<0.01$ ). And significant differences were also observed between control group and low

Table 1-1 Density of alveolar bone in the equivalency of aluminum

\begin{tabular}{l|c}
\hline \hline \multicolumn{1}{c|}{ Group } & Density \\
\hline Control & $2.15 \pm 0.18$ \\
\hline Ca-deficient $\cdot$ standard diet group & $1.88 \pm 0.11$ \\
\hline Ca-deficient $\cdot$ UNICAL ${ }^{\circledR}$ diet group & $1.77 \pm 0.13$ \\
\hline Low-Ca diet $\cdot$ standard diet group $^{-1.84 \pm 0.20}$ \\
\hline Low-Ca diet $\cdot \mathrm{UNICAL}^{\circledR}$ diet group & $1.84 \pm 0.01$ \\
\hline
\end{tabular}

Table 1-2 Difference of density of alverlar bone in the of aluminum equivalency

\begin{tabular}{c|c|c|c|c|c}
\hline & $\mathrm{A}$ & $\mathrm{B}$ & $\mathrm{C}$ & $\mathrm{D}$ & $\mathrm{E}$ \\
\hline $\mathrm{A}$ & & $* *$ & $* *$ & $*$ & $* *$ \\
\hline $\mathrm{B}$ & $* *$ & & - & - & - \\
\hline $\mathrm{C}$ & $* *$ & - & & - & - \\
\hline $\mathrm{D}$ & $*$ & - & - & & - \\
\hline $\mathrm{E}$ & $* *$ & - & - & - & \\
\hline & \multicolumn{5}{|c}{$* *: \mathrm{p}<0.01, *: \mathrm{p}<0.05$}
\end{tabular}
A : Control group
B : Ca-deficient $\cdot$ standard diet group
C : Ca-deficient $\cdot$ UNICAL $^{\circledR}$ diet group
D : Low-Ca diet - standard diet group
$\mathrm{E}$ : Low-Ca diet $\cdot \mathrm{UNICAL}^{\circledR}$ diet group 
Table 2 Analysis of $\mathrm{Ca}$ and $\mathrm{P}$ in alveolar bone by $\mathrm{X}$-ray microanalyzer

\begin{tabular}{l|c|c}
\hline \hline & $\mathrm{Ca}$ & $\mathrm{P}$ \\
\hline Control & $66.63 \pm 2.62$ & $33.37 \pm 2.62$ \\
\hline Ca-deficient $\cdot$ standard diet group & $62.82 \pm 0.65$ & $37.18 \pm 0.65$ \\
\hline Ca-deficient $\cdot \mathrm{UNICAL}^{\circledR}$ diet group & $62.82 \pm 0.78$ & $37.18 \pm 0.78$ \\
\hline Low-Ca diet $\cdot$ standard diet group & $66.27 \pm 1.36$ & $33.73 \pm 1.36$ \\
\hline Low-Ca diet $\cdot \mathrm{UNICAL}^{\circledR}$ diet group & $64.23 \pm 1.54$ & $35.77 \pm 1.54$ \\
\hline
\end{tabular}

Table 3 Relative percentages of $\mathrm{Ca}$ and $\mathrm{P}$ in alveolar bone by quantitative $\mathrm{X}-$ ray microanalyzer

\begin{tabular}{l|c|c}
\hline \hline & $\mathrm{Ca} /[\mathrm{Ca}] \mathrm{c}$ & $\mathrm{P} /[\mathrm{P}] \mathrm{c}$ \\
\hline Control & 1.00 & 1.00 \\
\hline Ca-deficient $\cdot$ standard diet group & 0.94 & 1.11 \\
\hline Ca-deficient $\cdot \mathrm{UNICAL}^{\circledR}$ diet group & 0.94 & 1.11 \\
\hline Low-Ca diet $\cdot$ standard diet group & 0.99 & 1.01 \\
\hline Low-Ca diet $\cdot \mathrm{UNICAL}{ }^{\circledR}$ diet group & 0.96 & 1.07 \\
\hline
\end{tabular}

calcium $\cdot$ standard diet group $(\mathrm{p}<0.05)$ (Table $1-1,1-2)$.

2. $\mathrm{X}$-ray microanalytic findings

By surface microanalysis, it has been found that density of calcium was higher than phosphorus in any group. In order to observe the change of calcium and phosphorus density, we calculate the relative proportion of calcium and phosphorus in every experimental group comparing against the control group. Significant differences were found by this quantitative analysis, the results were showed as $\mathrm{Ca} /[\mathrm{Ca}] \mathrm{c}$ and $\mathrm{P} /[\mathrm{P}] \mathrm{c}$. The results of $\mathrm{Ca} /[\mathrm{Ca}] \mathrm{c}$ were calcium deficient $\cdot$ standard diet group $<$ calcium deficient $\cdot \mathrm{UNICAL}^{\circledR}$ group $<$ low calcium UNICAL ${ }^{\circledR}$ group $<$ low calcium $\cdot$ standard diet group $<$ control group, while $\mathrm{P} /[\mathrm{P}] \mathrm{c}$ showed as control $<$ calcium deficient $\cdot$ standard diet group $<$ calcium deficient $\cdot$ UNICAL $^{\circledR}$ group $<$ low calcium $\cdot$ standard diet group $<$ low calcium $\cdot$ UNICAL $^{\circledR}$ group (Table 2,3 ).

3. Histopathological findings

Control group

It has been found that the new formation of bundle bone adjacent to periodontal membrane was thick, and successive lamellae were seen when investigated the lingual alveolus. The number of Haversian canal in this field increased, and the lacunae around it arranged concentrically. The architecture of Haversian system was distinct, and the lacunae in it arranged densely. The formation and resorption of bone in the surface of Haversian canal was distinct, and the bone restructured lamellae which were darkly stained by 


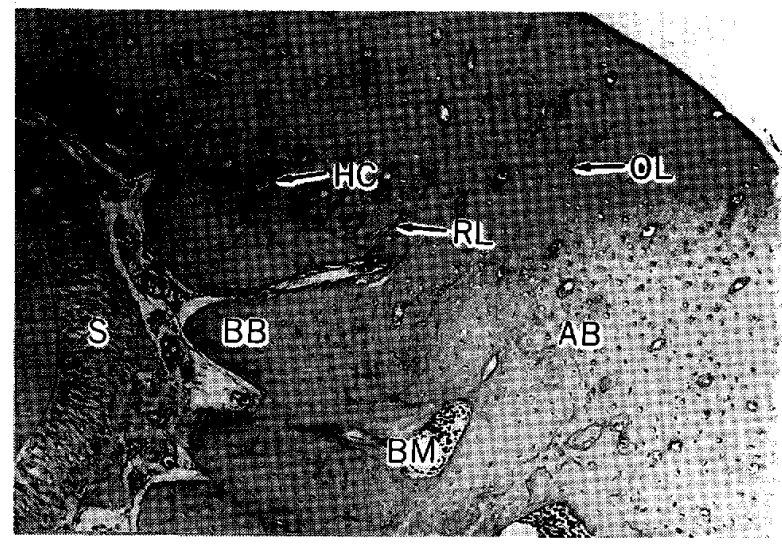

Fig. 1 Lingual alveolar bone of the 12 th week rat. Control group

$\mathrm{H} \cdot \mathrm{E}$ stain $(\times 50)$

The bundle bone, lamellae and compact bone is distinct, lots of Haversian canals can be seen and the bone remodeling is active.

AB : Alveolar bone

OL : Osteocytic lacunae

HC : Haversian canal

BM : Bone marrow

$\mathrm{BB}$ : Bundle bone

S : Sharpey's fiber

RL : Remodeling layer

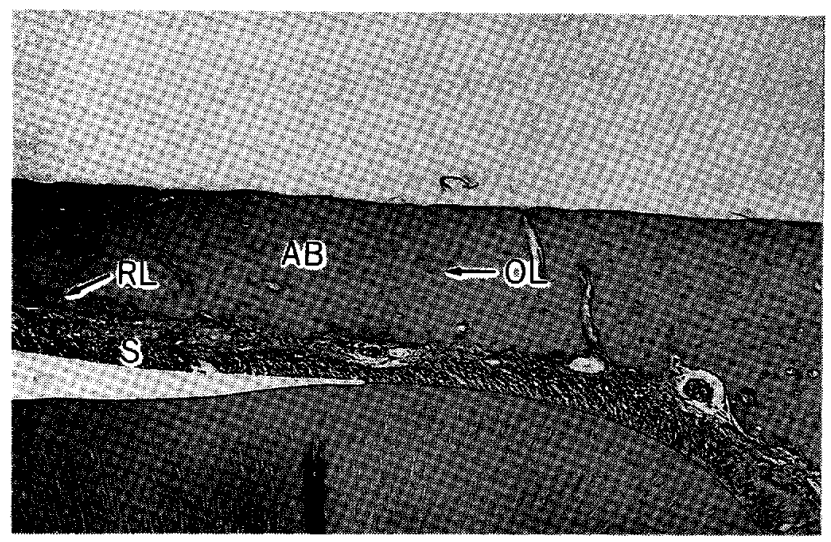

Fig. 2 Medial alveolar bone of the 12 th week rat. Control group

$\mathrm{H} \cdot \mathrm{E}$ stain $(\times 50)$

The resorption in the alveolus adjacent to periodontal membrane can be observed, and the formation is seen too. The arrangement of osteocy tic lacunae is regular.

AB : Alveolar bone (medial side)

OL : Osteocytic lacunae

$S$ : Sharpey's fiber

RL : Remodeling layer

hematoxylin and bone remodeling were active (Fig. 1).

The lacunae arranged regularly in the whole medial alveolus. Successive laciniate bone resorption was seen in the bone adjacent to periodontal membrane and the new bone formation in the same part was seen. The periodontal membrane in this field arranged irregularly (Fig. 2).

The thickness of buccal alveolus was thicker than medial alveolus. And the number of Haversian canal increased, bone remodeling was often seen. The number of lacunae adjacent to periodontal membrane decreased obviously, and no-structural osteoid was seen (Fig. 3).

A lot of lacunae and Haversian canals arranged in the labial alveolus. Compared with lingual alveolus, the number of lacunae decreased but the Haversian canals increased in inner part of labial alveolus (Fig. 4).

Calcium deficient standard diet group

Enlargement of bone marrow space and the decrease of trabeculae were seen in lingual alveolus. Compared with control group, the decrease of lamellae, the number of lacunae and Haversian canal were seen (Fig. 5).

Contrasted to lingual alveolus, there were lots of no-structural new bone were seen in the medial and buccul alveolus, in this field several osteocytes in a same lacunae and nostructural osteoid were often seen (Fig.6).

What was seen in the liable alveolus was similar as medial and buccul alveolus (Fig.7).

Calcium deficient $\mathrm{UNICAL}^{\circledR}$ group 
Dietary Therapy on Osteoporotic Mandibular Alveolus in Young Rats (Tsuruta, Y. et al.) - $417-$

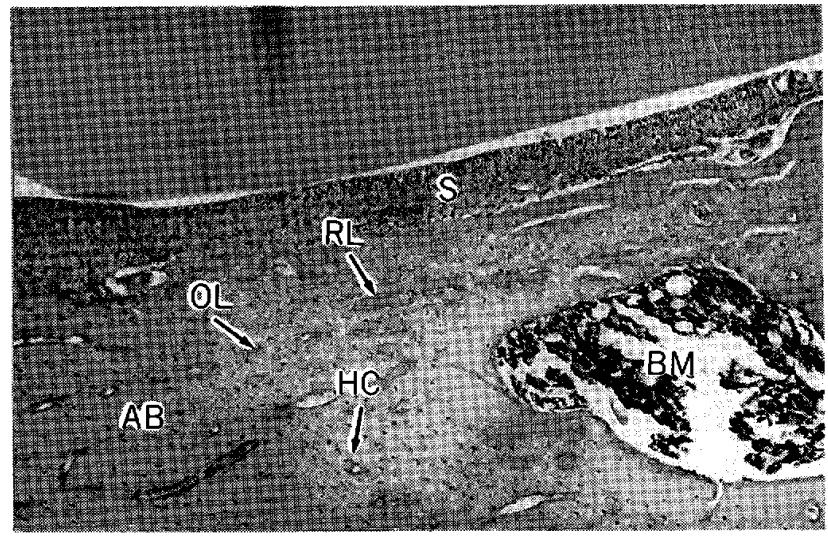

Fig. 3 Buccal alveolar bone of the 12 th week rat. Control group

$\mathrm{H} \cdot \mathrm{E}$ stain $(\times 50)$

The periodontal space is thick. The new bone formation, Haversian canal and active remodeling is like to what is seen in medial alveolus.

AB : Alveolar bone (buccal side)

OL : Osteocytic lacunae

$\mathrm{BM}$ : Bone marrow

S : Sharpey's fiber

RL : Remodeling layer

$\mathrm{HC}$ : Haversian canal

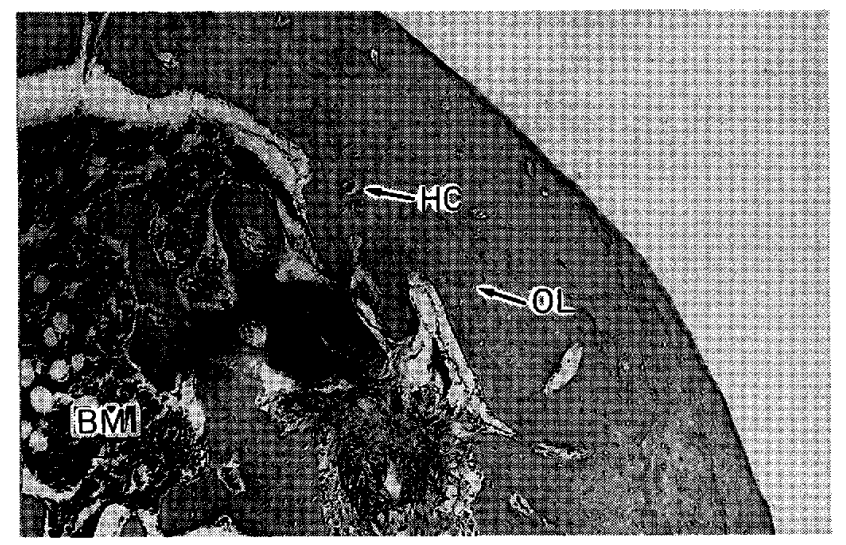

Fig. 5 Medial alveolar bone of the 12 th week rat. Calcium deficient standard diet group

$\mathrm{H} \cdot \mathrm{E}$ stain $(\times 50)$

The enlargement of bone marrow space is obvious, and the bone mass decrease.

OL : Osteocytic lacunae

$\mathrm{HC}$ : Haversian canal

$\mathrm{BM}$ : Bone marrow

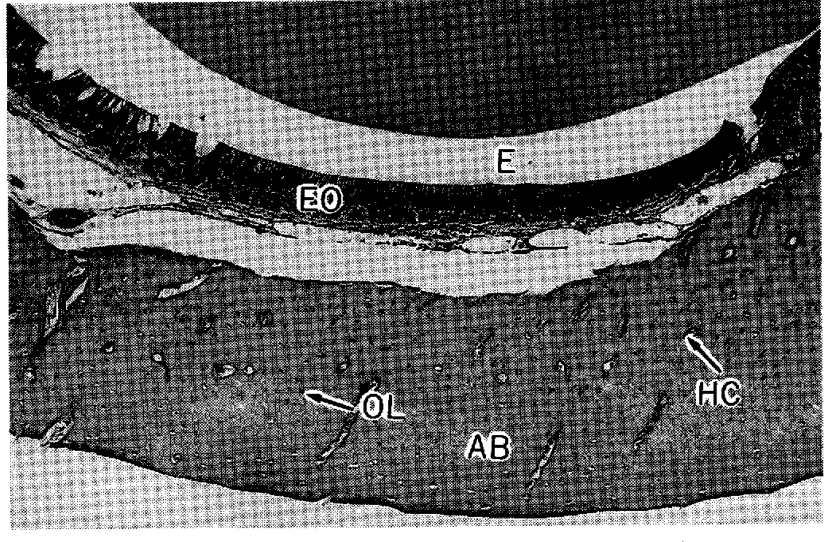

Fig. 4 Medial alveolar bone of the 12 th week rat. Control group

$\mathrm{H} \cdot \mathrm{E}$ stain $(\times 50)$

The Haversian system is distinct in this field.

AB : Alveolar bone

OL : Osteocytic lacunae

$\mathrm{HC}$ : Haversian canal

EO : Enamel organ

E : Enamel

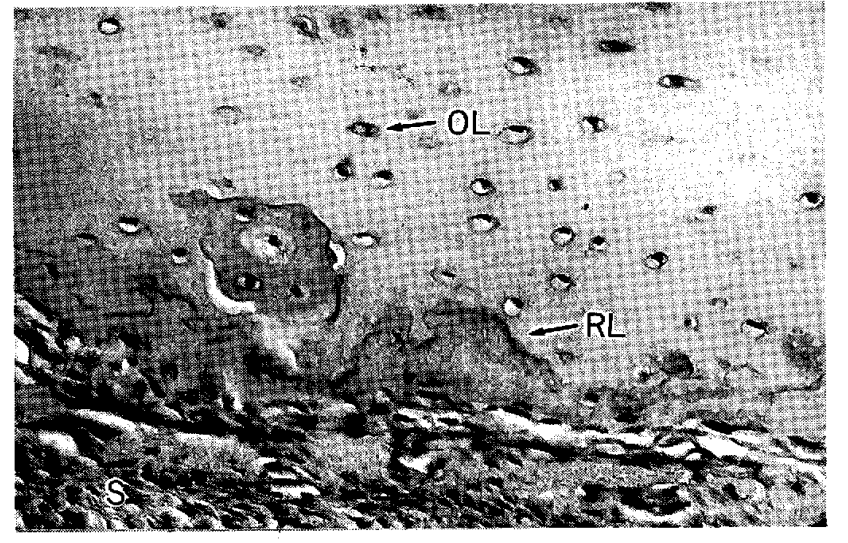

Fig. 6 Medial alveolar bone of the $12 \mathrm{~h}$ week rat. Calcium deficient standard diet group

$\mathrm{H} \cdot \mathrm{E}$ stain $(\times 200)$

The no-structure osteoid adjacent to periodontal membrane is observed.

OL: Osteocytic lacunae

$S$ : Sharpey's fiber

RL : Remodeling layer

The bone marrow space decreased and the number of Haversian canal increased when compared this group with calcium deficient standard diet group, and we saw new bone formation here and there. The number of lacunae was basically normal but the number of Haversian system decreased obviously. The shape of lacunae was varied such as oval, 


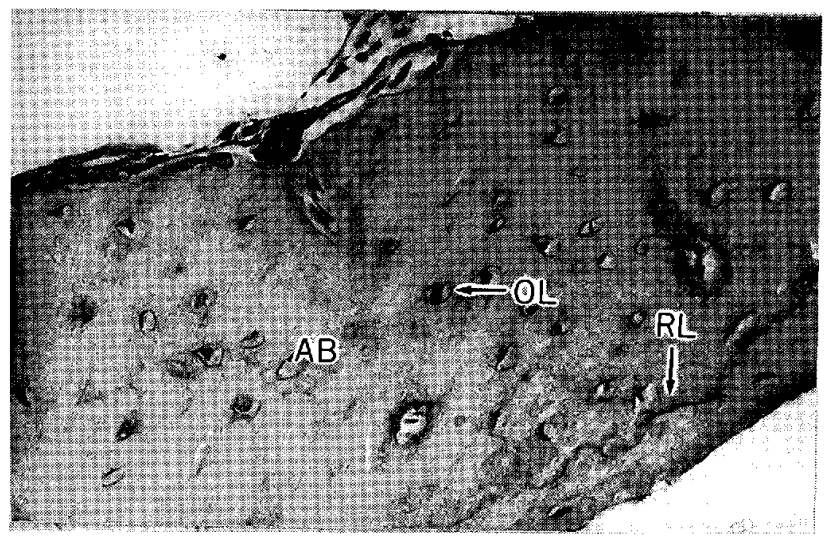

Fig. 7 Buccal alveolar bone of the 12 th week rat. Calcium deficient standard diet group

$\mathrm{H} \cdot \mathrm{E}$ stain $(\times 200)$

The Haversian canal is hardly seen. The number of osteocytic lacunae decreases and the arrangement of it is irregular.

$\mathrm{AB}$ : Alveolar bone (labial side)

OL : Osteocytic lacunae

$\mathrm{RL}$ : Remodeling layer

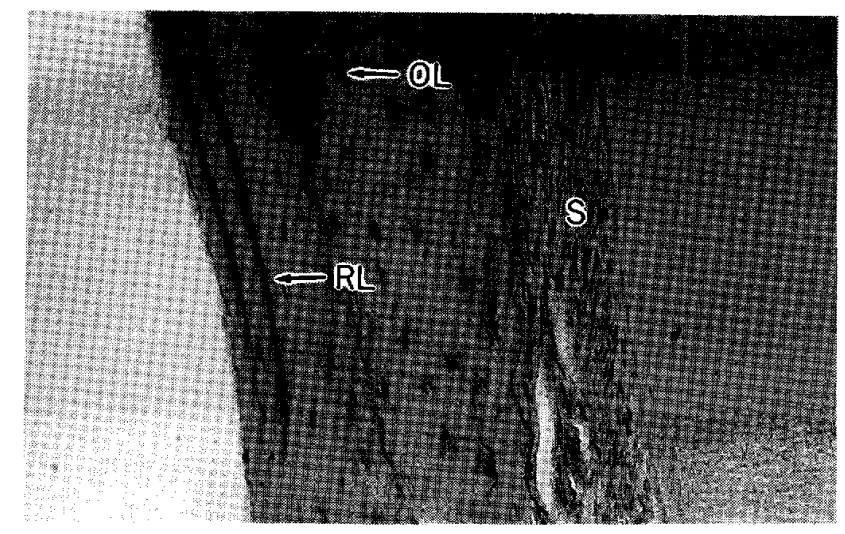

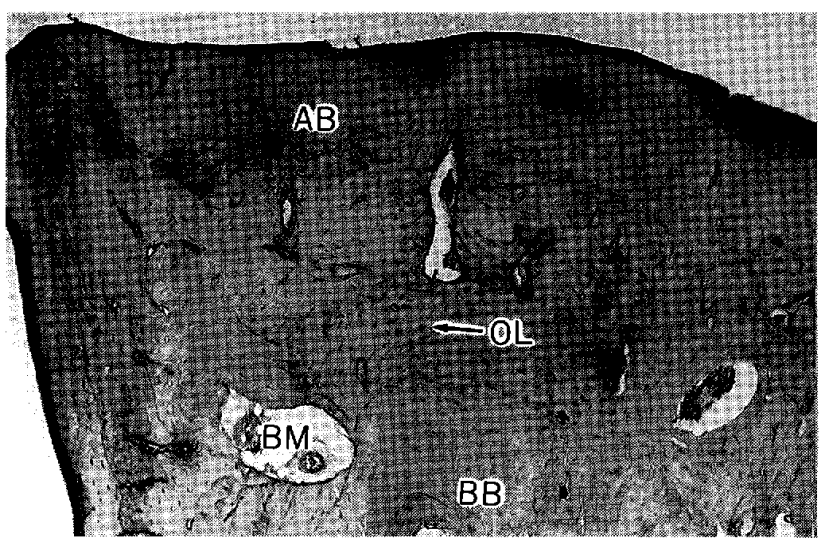

Fig. 8 Lingual alveolar bone of the 12 th week rat. Calcium deficient UNICAL ${ }^{\circledR}$ group

$\mathrm{H} \cdot \mathrm{E}$ stain $(\times 50)$

The bone marrow space is replaced by bone so it narrows obviously.

$\mathrm{AB}$ : Alveolar bone (lingual side)

OL : Osteocytic lacunae

$\mathrm{BM}$ : Bone marrow

$\mathrm{BB}$ : Bundle bone

Fig. 9 Medial alveolar bone of the 12th week rat. Calcium deficient UNICAL ${ }^{\circledR}$ group

$\mathrm{H} \cdot \mathrm{E}$ stain $(\times 200)$

The arrangement of periodontal is regular and thick osteoid is seen.

$\mathrm{OL}$ : Osteocytic lacunae

$S$ : Sharpey's fiber

RL : Remodeling layer

spindle, or rectangle (Fig. 8).

The periodontal space in buccal alveolus was thinner than that in medial alveolus, and trabeculae arranged regularly, but in the thin bone formation field which was adjacent to periodontal membrane the number of osteocytic lacunae was less than that in control group (Fig. 9).

The space of periodontal membrane was thick and the Shapey's fiber arranged regularly in the buccal alveolus, and close to it the thickness of new formational bone that was named as osteoid was thick.

What was seen in labial alveolus was the same as what was seen in calcium deficient standard group.

Low calcium standard diet group

There were thicker new formational bone in lingual, medial and buccal alveolus than in 
Dietary Therapy on Osteoporotic Mandibular Alveolus in Young Rats (Tsuruta, Y. et al.) - $-419-$

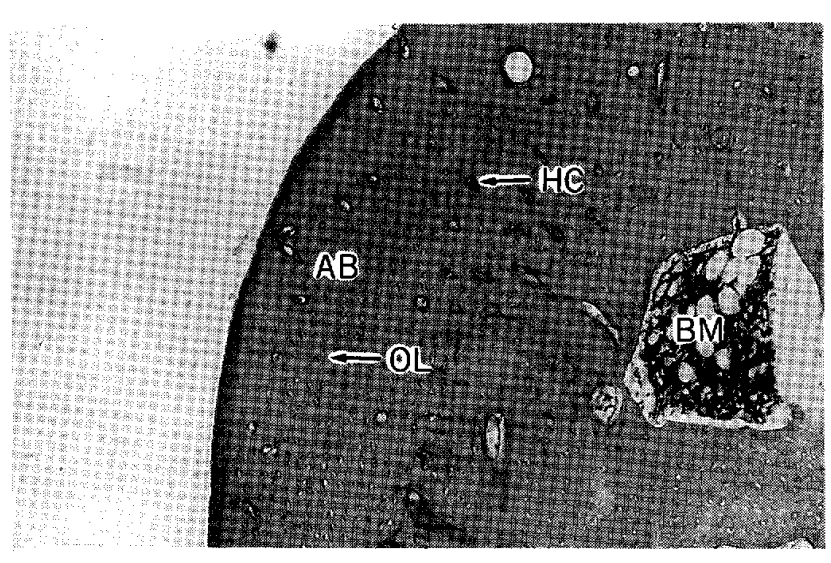

Fig. 10 Lingual alveolar bone of the 12 th week rat.

Low calcium standard diet group

$\mathrm{H} \cdot \mathrm{E}$ stain $(\times 50)$

The new formation of compact bone is thick and the lamellae central to bone marrow form thickly.

AB : Alveolar bone (lingual side)

OL : Osteocytic lacunae

HC : Haversian canal

$\mathrm{BM}$ : Bone marrow

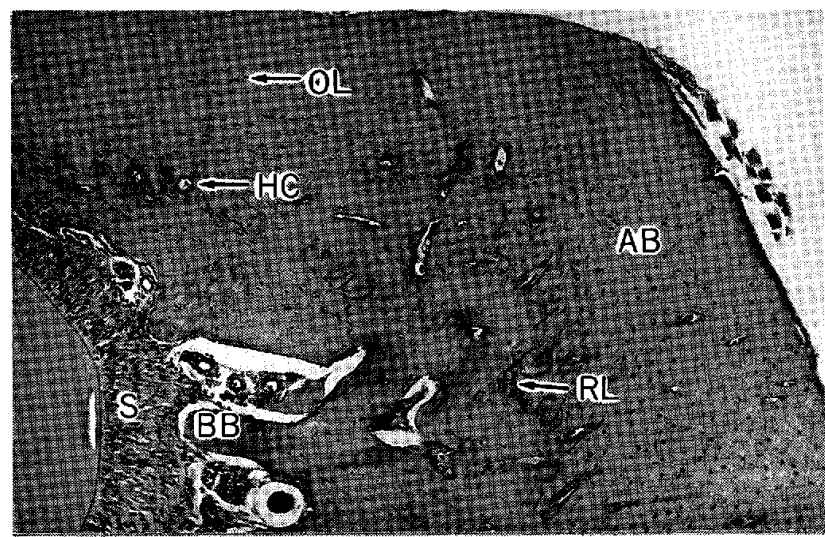

Fig. 12 Lingual alveolar bone of the 12th week rat.

Low calcium UNICAL ${ }^{\circledR}$ group

$\mathrm{H} \cdot \mathrm{E}$ stain $(\times 200)$

The distinct remodeling lamellae are adjacent to bundle bone which is formed from Sharpey's fiber. The arrangement of osteocy tic lacunae is regular.

AB : Alveolar bone (lingual side)

OL : Osteocytic lacunae

$\mathrm{HC}$ : Haversian canal

$\mathrm{BB}$ : Bundle bone

S : Sharpey's fiber

RL : Remodeling layer

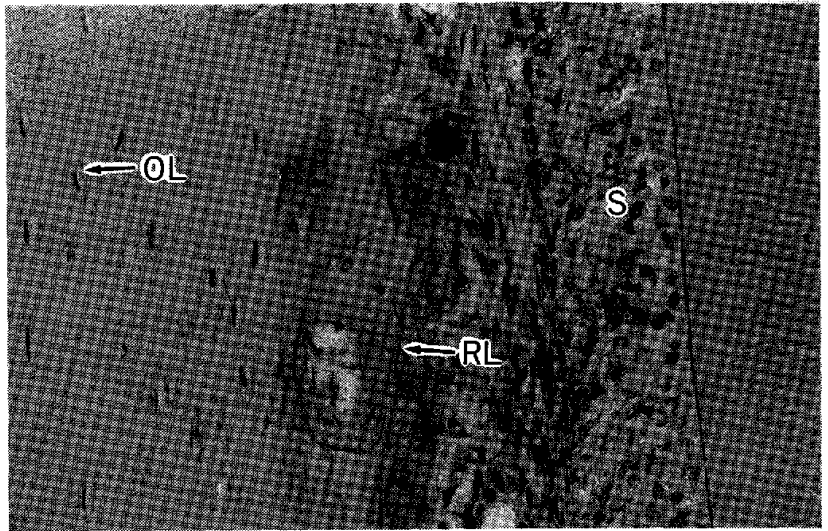

Fig. 11 Medial alveolar bone of the 12 th week rat. Low calcium standard diet group

$\mathrm{H} \cdot \mathrm{E}$ stain $(\times 200)$

The number of osteocytic lacunae in new bone increases.

OL: Osteocytic lacunae

$S$ : Sharpey's fiber

RL : Remodeling layer

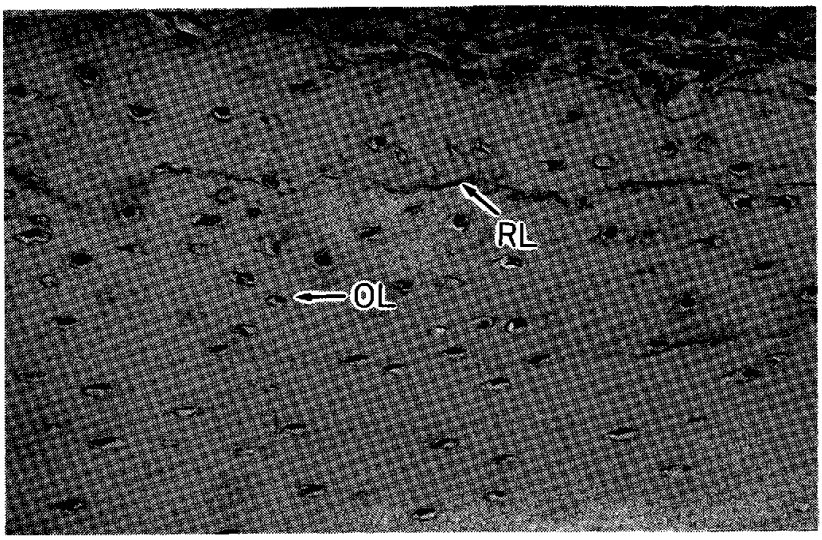

Fig. 13 Medial alveolar bone of the 12 th week rat. Low calcium UNICAL ${ }^{\circledR}$ group

$\mathrm{H} \cdot \mathrm{E}$ stain $(\times 200)$

The osteocytic lacunae, in the remodeling lamellae that is near to thick bundle bone, arrange regularly. OL : Osteocytic lacunae

RL : Remodeling layer 
calcium deficient UNICAL ${ }^{\mathbb{B}}$ group, and this group was characterized by the increase of the number of Harversian system and osteocytic lacunae in lamellae (Fig. 10, 11).

In the labial alveolus, what was seen was the same as that in calcium deficient $\mathrm{UNICAL}^{\circledR}$ group.

Low calcium UNICAL ${ }^{\circledR}$ diet group

This group was characterized by the increase of the number of lacunae that were in bundle bone and lamellae bone when compared with control group. And the number of Harversian system increased too. The lacunae in remodeling lamellae and compact bone arranged regularly, and the bone matrix was the same as control group (Fig.12).

It was often seen that the lacunae were embedded in the new formational bone in the medial and buccal alveolus (Fig. 13). What was seen in the labial alveolus was the same as that in control group.

\section{Discussion}

Bone is a living tissue, and the formation and resorption of it take place throughout the whole life. The serum level of calcium and phosphorus were regulated strictly accompanied by the renewing of bone. Calcium is an essential ion in many kinds of cell for the conduction of nervous stimulant, contract of muscle and metabolism of energy, this ion is necessary to maintain the normal life activity. At the end of development, the differentiation stopped and the balance between calcium absorption in intestine and calcium excrement of the whole body is maintained, and the balance of bone between formation and resorption is kept too. But if the amount of calcium absorbed in intestine decrease, the balance will be destroyed, and calcium will be taken from bone which serve as calcium store, if this process keep for a long time it will result in bone resorbed ${ }^{3)}$. This is a main reason in retrograde osteoporosis and menopausal osteoporosis in which the secretion of female hormone decreased $^{4}$. Now dentists pay attention on osteoporotic jawbones because osteoporosis is a risk factor for periodontal disease and it is difficult to plant an implant into osteoporotic jawbones, ${ }^{5,6}$.

The secondary sexual characteristic period is the most active period in the childhood, and peak bone mass was reached in this period. Maximizing the peak bone mass at skeletal maturity is one of preventive measures for osteoporosis.

In the present study, we aimed to study the effect of dietary therapy of $\mathrm{UNICAL}^{\circledR}$ on osteopenia in young rats. UNICAL ${ }^{\circledR}$ is made from sea shell, and it has been demonstrated that $\mathrm{UNICAL}^{\circledR}$ showed a high rate of absorption in rats' intestine ${ }^{\text {) }}$, and it is composed of balanced minerals. In this study, we research the effects of UNICAL ${ }^{\circledR}$ on bone matrix formation in osteoporotic mandible of young rats.

1. Microphotometric findings

$\mathrm{X}$-ray photos have been widely used to grasp the structure of bone and elucidated it quantitatively, the MD (Microdensitometry method) is one of useful method. Watanabe $(1995)^{8)}$ reported that low calcium diet group showed lower density than control group in 8- 
week-old rats. But Kimura $(1997)^{9)}$ reported contradictory result that no significant difference was found between control group, calcium deficient group and low calcium group in cortical bone of 5-week-old and 8-week-old rats. And it was thought that even the osteopenia was caused in adolescence, it could be recovered completely by dietary therapy.

In clinic study, measuring the density of mandible between 6-year-old to 8-years-old children, Maki et al. (1993) ${ }^{10)}$ reported that there were interrelation between the bone mineral quantity of the mandibular and age. The same authors (1994) ${ }^{11)}$ reported that there were close interrelation between density of mandible and the thickness of the base of mandible cortical bone. Then the same researchers reported $(1994)^{12)}$ that there were interrelation between occlusion force and bone density in a group of 8-year-old to 10-year-old children, and the reason for it was considered as bone response to masticatory force. And Kimura $(1996)^{13)}$ reported that there were significant differences in mandible density between Chinese and Japanese children, and there were interrelation between bone density and thickness of the base of mandible cortical bone.

In our study, significant differences were observed between the calcium deficient $\cdot$ standard diet group and calcium deficient $\cdot \mathrm{UNICAL}^{\circledR}$ group $(\mathrm{p}<0.01)$. And significant differences were also observed between control group, low calcium.standard diet group and low calcium. UNICAL $^{\circledR}$ group $(p<0.05)$. The reasons for the results were thought that one week is too short for bone to recover from osteopenia, and the bone density could not recover to normal in so short time. And no significant differences were found between low calcium standard diet group and low calcium $\cdot$ UNICAL ${ }^{\circledR}$ diet group, calcium deficient $\cdot$ standard diet group and calcium deficient - UNICAL ${ }^{\circledR}$ diet group. So it can be deduced that there is no difference of therapy effects between standard diet and UNICAL ${ }^{\circledR}$.

2. X-ray microanalytic findings

It had been reported by Sakamoto $(1994)^{14)}$, Ono $(1995)^{15)}$ and Saito $(1998)^{16)}$, that in the same trabeculae calcium concentration was shown higher than phosphorus in both control and experimental treatments. Kaku (1992) ${ }^{17)}$ reported that significant difference was found between control group and experimental group, and the control group showed higher value.

In this study, it has been found that calcium concentration was shown higher than phosphorus in both control and experimental treatments. We calculate the relative proportion of calcium and phosphorus of experimental treatments to the control group and found that the proportion of calcium in $\mathrm{UNICAL}^{\circledR}$ diet group was lower than in standard diet group. We drew a conclusion that dietary therapy could recover the osteopenia and the absorption of UNICAL ${ }^{\circledR}$ diet was easier than standard diet.

3 . Histopathological findings

The development of mandible is intramembranous. The alveolus of rat is divided into two parts, one is labial alveolus that was close to the connective tissue, the other is lingual alveolus that is composed of remodeling compact bone in which bundle bone and Haversian system are often seen. The mechanical stimulants originating from occlusion and masticatory force result in alveolus remodeling, the formation and resorption of mandible take place 
repetitiously all through the life. In general, an insufficient intake of calcium in developmental period can result in osteopenia, and the thickness of low calcified zone increase, bone marrow spaces enlargement and bone mass decrease are often seen which indicate that insufficiency of calcium in developmental period is a risk factor for osteopenia. Umezu $(1991)^{18)}$ reported that debilitating bone resulting from insufficient intake of calcium is recoverable by standard diet, and the increase of bone mass, bone renewing and remodeling was observed. Moreover better results would be gotten if giving them high calcium diet. Contrary report was given by Weinreb et al. $(1991)^{19)}$ that no changes were seen in 6 -weekold rats corresponding to child in human fed with low calcium diet. Kimura $(1996)^{13)}$ did the same experiment and reported that calcium deficient diet resulted in osteopenia and dietary therapy was able to recover bone from osteopenia.

The enlargement of bone marrow and the number of trabeculae, lamellae, and lacunae decrease which accompanied with the number of Haversian canals decrease were seen in the lingual alveolus bone of calcium deficient standard diet group, all of which showed that the bone had fallen into osteopenia. In the medial and buccal alveolus, the active remodeling bones were seen, which indicated that it was effective for osteopenia to feed rats on standard diet for one week. As compared with calcium deficient standard diet group, the decrease of bone marrow spaces and increase of Haversian canals were seen manifestly in calcium deficient UNICAL ${ }^{\circledR}$ diet group, which suggested that the UNICAL ${ }^{\circledR}$ diet was more effective against osteopenia than standard diet. The new thin bone addition at medial and buccal alveolus that is close to periodontal membrane was seen. The number of lacunae did not decrease in the whole lamellae which was different from what was seen in standard diet group, and the new no-structural bone were thick in the absorbed area of buccal alveolus. The UNICAL ${ }^{\circledR}$ was absorbed easier than standard diet and the recovering effect of it was more obvious than standard diet, which was considered as one of the reason for the difference between $\mathrm{UNICAL}^{\circledR}$ and standard diet. But one week was too short for bone to recover from osteopenia.

The newly formed bone in the absorbed area being close to periodontal membrane of lingual, medial and buccal alveolus was thicker in low calcium standard diet group than in calcium deficient UNICAL ${ }^{\circledR}$ diet group and the number of lamellae and Haversian system increased in the former group. In low calcium UNICAL ${ }^{\circledR}$ diet group the following was seen, the number of lacunae in bundle and lamellae bone increased; Haversian systems were welldeveloped; the remodeling at the surface of Haversian canal and the regularly arranged lacunae. The observed bone matrix formation in this group was same as what was seen in control group. From these results obtained, we thought that if sufficient calcium of UNICAL $^{\circledR}$ was supplied to the osteopenic rats caused by insufficient calcium intake in childhood, the osteopenia was recoverable even though the UNICAL ${ }^{\circledR}$ diet was given only one week.

The similar results were reported by Morimoto $(2000)^{20)}$, in which the osteopenia caused by insufficient calcium intake was recoverable by using $\mathrm{UNICAL}^{\circledR}$ diet too. From these results 
Dietary Therapy on Osteoporotic Mandibular Alveolus in Young Rats (Tsuruta, Y. et al.) - $423-$

we drew a conclusion that osteopenia could be recovered by sufficient calcium supply even though the osteopenia was caused the developmental and growing period.

\section{Conclusion}

In the present study, we fed the young rats that were in the secondary sexual characteristic period on calcium deficient diet so that the osteopenia of mandible, which was thought as a reason for the declining of occlusion force and masticatory ability. After that we researched the effect of dietary therapy on the matrix formation of mandible. The high calcium diet was made from sea shell, called UNICAL ${ }^{\circledR}$. The results were shown as follows.

1. Microphotometric findings

Significant differences were observed between the control group, calcium deficient * standard diet group, calcium deficient $\cdot \mathrm{UNICAL}^{\circledR}$ group and low calcium · UNICAL ${ }^{\circledR}$ group (p $<0.01$ ). And significant differences were also observed between control group, low calcium $\cdot$ standard diet group $(\mathrm{p}<0.05)$.

2. X-ray microanalysis of $\mathrm{Ca}$ and $\mathrm{P}$

By surface microanalysis, it has been found that density of calcium was higher than phosphorus in any group. Significant differences were found by quantitative analysis which was done by calculating the calcium and phosphorus relative proportion against control group, showed as $\mathrm{Ca} /[\mathrm{Ca}] \mathrm{c}$ and $\mathrm{P} /[\mathrm{P}] \mathrm{c}$. The results of $\mathrm{Ca} /[\mathrm{Ca}] \mathrm{c}$ were calcium deficient . standard diet group $<$ calcium deficient $\cdot \mathrm{UNICAL}^{\circledR}$ group $<$ low calcium $\cdot \mathrm{UNICAL}^{\circledR}$ group $<$ low calcium - standard diet group $<$ control group, while $\mathrm{P} /[\mathrm{P}] \mathrm{c}$ showed as control $<$ calcium deficient $\cdot$ standard diet group $<$ calcium deficient $\cdot \mathrm{UNICAL}^{\circledR}$ group $<$ low calcium $\cdot$ standard diet group $<$ low calcium $\cdot$ UNICAL $^{\circledR}$ group.

3. Histopathological findings

As contrasted to control group, the enlargement of marrow space and decrease of trabeculae were obviously in calcium deficient standard diet group. Bone osteopenia was obviously seen such as decrease of lamellae and lacunae. Compared with calcium deficient standard diet group, the calcium deficient UNICAL ${ }^{\circledR}$ group showed decreased marrow space and bone remolding, but the number of lacunae decreased obviously and bone still fell into osteopenia when compared with control group. Thicker new bone was seen often in low calcium standard diet group than in calcium deficient UNICAL ${ }^{\circledR}$ group, the number of Haversian system and lacunae increased too. In low calcium UNICAL group the formation of bone matrix was the same as what was seen in control group.

From these results having been gotten, we drew a conclusion that osteopenia could be recovered by sufficient calcium supply even though the osteopenia was caused in the developmental and growing period.

\section{Reference}

1) Suki, W. N. and Rouse, D.: Renal transport of calcium, magnesium, and phosphate. The kidney (ed By Brenner B. M). Philadelphia: W. B. Saunders, 1996: 472-515. 
2) Suino, Y., Tanaka, H., Nishiyama, Y. and Hirota, T.: The peak bone mass and relative factors. The bone $8: 16-34,1994$.

3) Liu, C. C. and Baylink, D. J.: Differential response in alveolar bone osteoclasts residing at two different bone sites. Calcif. Tissue Int. 36: 182-188, 1994.

4) Wu, H., Deng, X. and Wang, Y.: Relationship between osteoporosis and metabolism of calcium and bone, Hunan I Ko Ta Huseh Huseh Pao 23(3) : 261-264, 1998.

5 ) Loza, J. C., Carpio L. C. and Dziak R.: Osteoporosis and its relationship to oral bone loss. 3: 27-33, 1996.

6) Hileboit, C. F.: Osteoporosis and bone loss. Dentomaxillofac. Radiol. 26(1) : 3-15, 1997.

7) Animal care Co., Ltd.: A report of technical center. Animal care, Tokyo, 1994.

8) Watanabe, M. : An experimental study on juvenile bone debility in the jaw bones at the growing stage of rats (on alveolar bone). J. Kyushu Dent. Soc. 49: 20-40, 1995.

9) Kimura, K.: Radiological bone mass and histopathological study on diet therapy for bone debility in the rat at the growth stage. J. Kyushu Dent. Soc. 51: 41-72, 1997.

10) Maki, K., Ge, LH., Kimura, K., Aramaki, T., Syu, T., Yamano, H., Nozawa, N. and Kimura, M.: A clinical study on bone mineral quantity in the mandibular base in childhood. Japan J. Ped. Dent. 31 (3) : 404-411, 1993.

11) Maki, K., Ge, LH., Tsuruta, Y., Nakashima, R., Kaku, A., Takeshita, N., Takaesu, N. and Kimura, M.: A study on bone mineral content quantity in the mandible and thickness of the cortical bone at mandibular base (clinic evaluation at school ages). Japan J. Ped. Dent. 31(5) : 879-886, 1993.

12) Maki, K., Ge, LH., Kimura, K., Yoshinaga, H., Matsuda, Y., Furusawa, Y., Osato, Y. and Kimura, M.: A clinic study of occlusal force and bone salt's of school-age children. Japan J. Ped. Dent. 32 (3) : 488-493, 1994.

13) Kimura, M. and Shi, KX.: A comparative clinic study between Chinese and Japanese children on the bone mineral content and cortical bone thickness in mandible. J Japan Chinese Med. 11: 18-20, 1996.

14) Sakamoto, Y.: A light and scanning electron microscopic study on a combined treatment method of calcium and calcitonin for debilitated mandibles. J. Kyushu Dent. Soc. 48: 6-28, 1994.

15) Ono, S.: An experimental study on a combined treatment method of a high-calcium diet and calcitonin on alveolar bone debility. J. Kyushu Dent. Soc. 49: 70-90, 1995.

16) Saito, A.: Radiographic, microscopic and ultrastructural study on dietary treatment of mandibular bone loss at growth stage: formation of bone matrix. J. Kyushu Dent. Soc. 52: 1-32, 1998.

17) Kaku, A.: A radiological, light microscopic, and ultramicro-morphological study on the formation of bone matrix in the tibia. J. Kyushu Dent. Soc. 48: 554-574, 1994.

18) Umezu, T.: Radiological, and light and scanning electron microscopic study on the effect of highcalcium food on bone debility. J. Kyushu Dent. Soc. 45:629-652, 1991.

19) Weinreb, M., Rodan, G. A. and Thompson, D. D.: Immobilization-related bone loss in rat is increased by calcium deficiency. Calcif. Tissue Int. 48: 93-100, 1991.

20) Morimoto, A.: Effects of Unical diet on the development of the mandibular condyle cartilage at the growth stage. J. Kyushu Dent. Soc. 54: 1-19. 2000. 


\title{
若年期の虚弱下顎歯槽骨における 食餌療法に関する実験的研究
}

一骨基質形成一

\author{
鶴 田靖・西 岡 孝 浩・夏斌 \\ 牧憲 司・内上堀 征 人 \\ 九州㐘科大学小児歯科学講座（指導：木村光孝教授）
}

生後 8 週齢の Wistar 系雄ラット 30 匹を用いた。

対照群：ラット標準飼料（オリエンタル醉母工業）と 水道水で 4 週間飼育した。

カルシゥム欠乏食・標準食群: A 食変型カルシウム欠 乏飼料と蒸留水で 3 週間飼育し, 虚弱骨を惹起させた 後, 標準飼料と水道水に切り換え 1 週間飼育した.

カルシゥム欠乏食・ユニカル食群: $\mathrm{A}$ 食変型カルシウ 么欠乏飼料之蒸留水で 3 週間飼育し, 虚弱骨を惹起させ た後, ユニカル食と水道水に切り換え 1 週間飼育した.

低カルシウム食・標準食群：A 食变型低カルシゥム飼 料（30\%）と水道水で 3 週間飼育し, 虚弱骨を惹起させ た後, 標準飼料に切り換え 1 週間飼育した。

低カルシゥム食・ユニカル食群: A 食変型低カルシウ 么飼料 $(30 \%)$ と水道水で 3 週間飼育し, 虚弱骨を惹起 させた後，ユニカル食に切り換え 1 週間飼育した.

\section{1. 骨塩量}

対照群とカルシゥム欠乏食・標準食群, カルシウム欠 そ食・ユニカル群の間に有意差がみられた $(\mathrm{p}<0.01)$.
対照群と低カルシウム食・標準食群, 低カルシウム食・ ユニカル食群の間に有意差がみられた $(\mathrm{p}<0.05)$.

\section{2. 病理組織所見}

対照群に比へ， カルシウム欠乏食·標準食群は骨䯣の 拡大, 骨梁の減少が著明である. 層板骨は減少し, 骨小 腔の大偪な減少など骨虚弱の状態が明らかである。カル シウム欠乏食・ユニカル食群はカルシゥム欠乏食・標準 食群と比へ骨骾が大幅に縮小し, 骨構築の回復がみられ るが，対照群と比べ骨小腔は大幅に減少しているなどま だ骨虚弱の状態がみられる. 低カルシウム食・標準食群 はカルシゥム欠乏食・ユニカル食群と比べ厚い新生骨の 添加がみられ，層板骨でのハバース系と骨小腔の増加が みられる. 低カルシウム食・ユニカル食群は対照群と比 へ，骨基質形成は対照群と同様な所見を呈している.

以上の結果から一時期骨虚弱状態になったとしても, ユニカル食餌療法を行うことにより骨吸収から骨形成の ための成長期の骨代謝が正常に行われ骨の回復が可能で あることが示唆された. 